\title{
Micropropagation and in vitro grafting techniques to assist the selection of a pistachio rootstock from a population of terebinth (Pistacia terebinthus L.) collected in the SE of Spain
}

E. Garcia1; I. Imbroda²; P. Lorente1; J.A. Marín¹; A. Arbeloa1; I.M.G. Padilla²; A. Barceló2; P. Andreu

${ }^{1}$ Estación Experimental de Aula Dei-CSIC. Apartado 13034, 50080 Zaragoza, Spain

2IFAPA, Cortijo de la Cruz s/n, Churriana, 29140 Málaga, Spain

egarcia@eead.csic.es

\begin{tabular}{|l|l|}
\hline Background & $\begin{array}{l}\text { Pistachio culture is becoming highly interesting in Spain, } \\
\text { where traditional crops as grape and olive have reduced } \\
\text { their profitability. However, its expansion is hampered } \\
\text { both by the difficulty of grafting varieties of interest on } \\
\text { selected rootstocks, and by the lack of a selected clonal } \\
\text { rootstock. }\end{array}$ \\
\hline What & $\begin{array}{l}\text { Collecting and selecting well adapted autochthonous } \\
\text { clones of } P \text {. terebinthus in the wild. } \\
\text { Applying in vitro culture techniques for the clonal } \\
\text { propagation of Pistacia species as well as for studying } \\
\text { factors affecting grafting. }\end{array}$ \\
\hline How & $\begin{array}{l}\text { Improving the germination protocol of Pistacia seeds. } \\
\text { Optimizing the culture medium for both, scion and variety. } \\
\text { Setting up a suitable grafting technique in vitro as a model } \\
\text { to study grafting evolution. }\end{array}$ \\
\hline
\end{tabular}

Germination. Collected mature seeds from $P$. Rooting. Shoots of $P$. terebinthus were rooted on terebinthus trees were treated with Ethrel, Nufarm two different media. Rooting percentage in WPM $(2 \%)$, for $24 \mathrm{~h}$ at $4-5^{\circ} \mathrm{C}$. Seeds were sowed in (78 shoots) or MS (24 shoots) was recorded after forestall cells containing a mixture of peat: coconut $4-8$ weeks.

fiber: perlite. Germination data were recorded every other week and length and number of nodes at the $8^{\text {th }}$ week.

In vitro grafting. In vitro $P$. vera shoot tips $(1-2 \mathrm{~cm}$ length) were grafted in vitro on rooted or unrooted shoots of $P$. terebinthus (4 cm length) with their Establishment. P. terebinthus shoots were taken apexes removed. Scions with the base cut in $\mathrm{v}$ from seedlings. Simultaneously, one-node explants shape were fitted onto vertical slits made on the of $P$. vera plants grown in the field were taken in decapitated rootstocks. Homografts of $P$. spring and disinfected with $0.05 \% \mathrm{HgCl}_{2}$. Multiplication. Three different media (DKW, WPM, Histological wsudes wer 4-8 MS) were tested. Shoots were subcultured every weeks following grafling. Cen proliferation and three weeks and culture media were compared difer attending to: apical necrosis (\%), average shoot con length $(\mathrm{mm})$, number of internodes per shoot and recorded following $0.01 \%$ acridine orange stain multiplication rate (number of shoots per shoot).

\section{Germination of $\boldsymbol{P}$. terebinthus seeds}
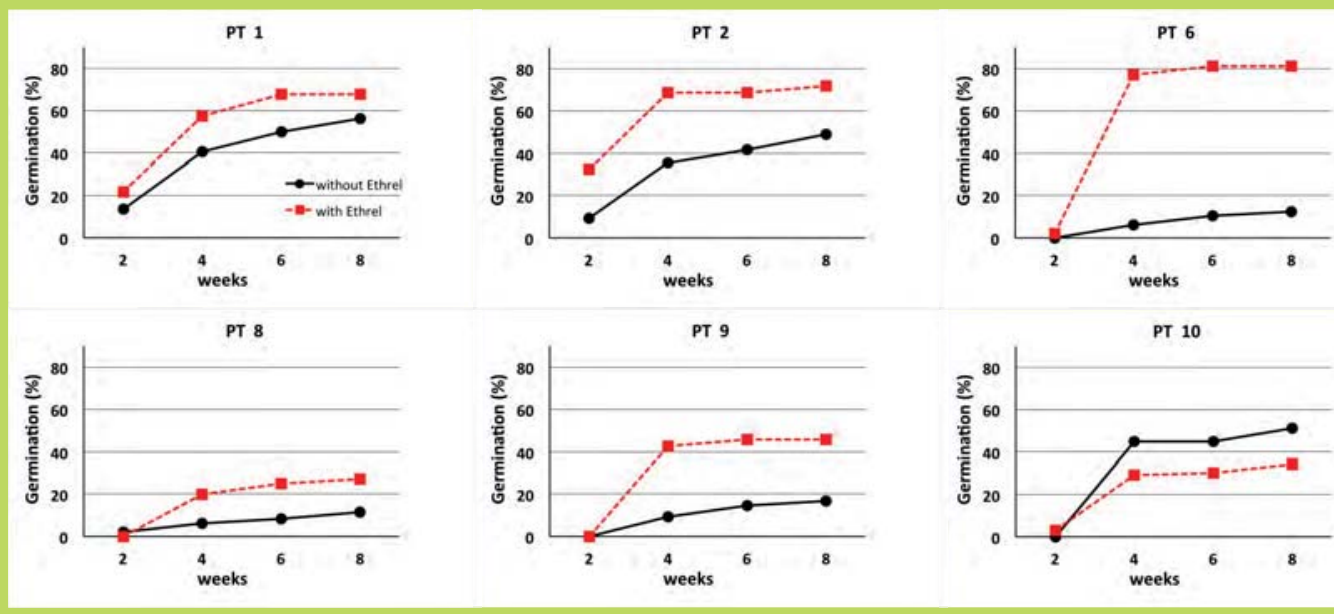

\section{Selected $P$. terebinthus trees (PT1, 2, 6, 8, 9, 10) showed different degree of germination capability and vigour. \\ Ethrel significantly improved germination rate as well as seedling growth, except in seeds from PT10, where the effect was adverse.}

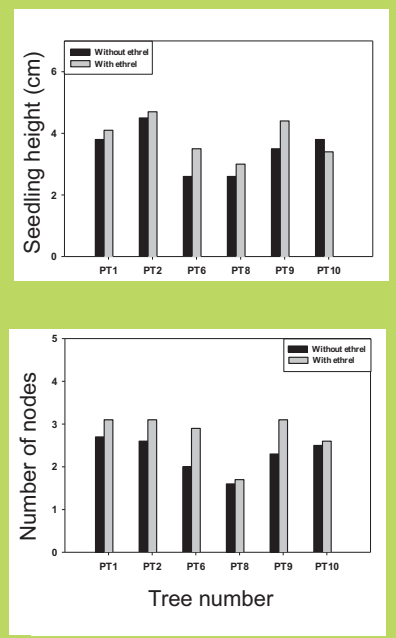

\section{Micropropagation}

Survival of $P$. vera initial nodal explants was $40 \%$. Germination of $P$. terebinthus ranged from $27 \%$ to $80 \%$ after 4 to 6 weeks.

DKW culture medium was better in reducing apical necrosis than MS or WPM, while obtaining good multiplication rates. Rooting was achieved in modified WPM medium in $82 \%$ of the shoots but decreased to $42 \%$ in modified MS medium. Plants were successfully transferred to the greenhouse.
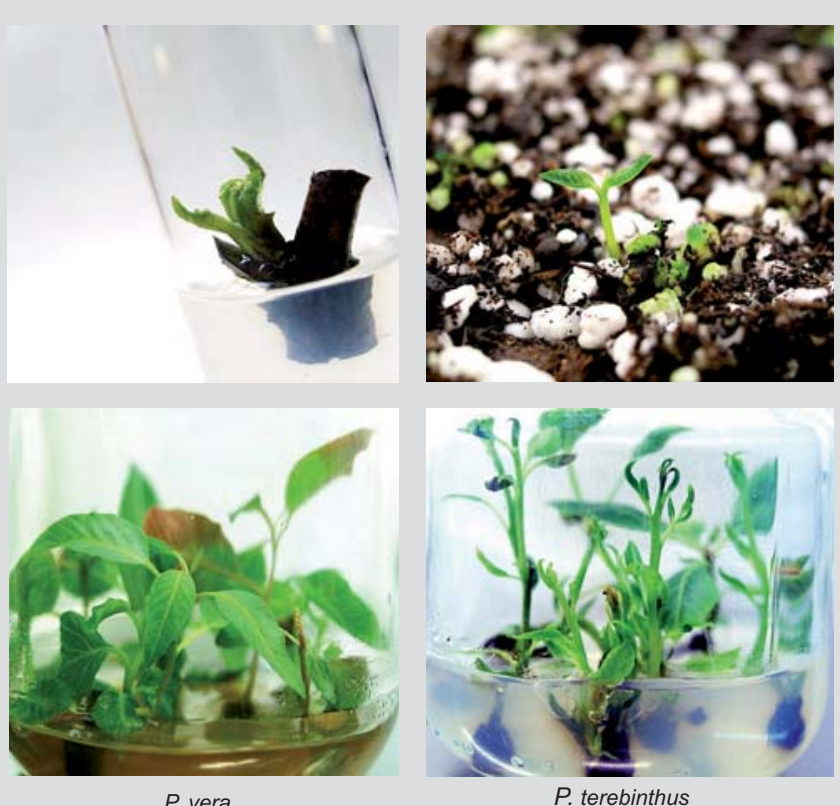

\begin{tabular}{|c|c|c|c|c|c|}
\hline & $n$ & Length (mm) & $\begin{array}{l}\text { Number of } \\
\text { internodes }\end{array}$ & Multiplication rate & Apical necrosis(\%) \\
\hline \multicolumn{6}{|l|}{ P. vera } \\
\hline DKW & 111 & $23.68 \pm 1.00 a$ & $6.3 \pm 0.20 \mathrm{a}$ & $2.5 \pm 0.11 b$ & $25.22 \mathrm{C}$ \\
\hline MS & 112 & $17.46 \pm 0.61 \mathrm{c}$ & $4.9 \pm 0.15 b$ & $2.1 \pm 0.09 c$ & $47.32 b$ \\
\hline WP & 112 & $20.64 \pm 0.75 b$ & $5.1 \pm 0.16 \mathrm{~b}$ & $3.5 \pm 0.17 \mathrm{a}$ & $\underset{* * *}{61.61 a}$ \\
\hline \multicolumn{6}{|c|}{ P. terebinthus } \\
\hline DKW & 30 & $30.9 \pm 3.25 a$ & $6.1 \pm 0.36 \mathrm{a}$ & $1.8 \pm 0.13$ & $10.0 b$ \\
\hline MS & 30 & $19.8 \pm 1.45 b$ & $4.9 \pm 0.28 b$ & $1.8 \pm 0.19$ & $36.7 a$ \\
\hline WP & 30 & $20.5 \pm 1.48 \mathrm{~b}$ & $4.1 \pm 0.28 b$ & $\begin{array}{c}1.9 \pm 0.15 \\
\text { n.s. }\end{array}$ & 26.7ab \\
\hline
\end{tabular}

Mean values $( \pm \mathrm{s}$ e $\mathrm{m}$ ) of shoot length, number of internodes, multiplication rate and the percentage of apical necrosis ( ${ }^{*}, * * *, n . . s .: P<0.05, P<0.001$, not significant, respectively; n: sample size)

\section{In vitro grafting}

Most of the grafts showed cell proliferation and cell differentiation at the graft interface.

Despite the fact that the technique must be improved to reduce the presence of necrotic cells that are also present in $P$. terebinthus homografts, in vitro grafting studies opens a way to monitor graft evolution.

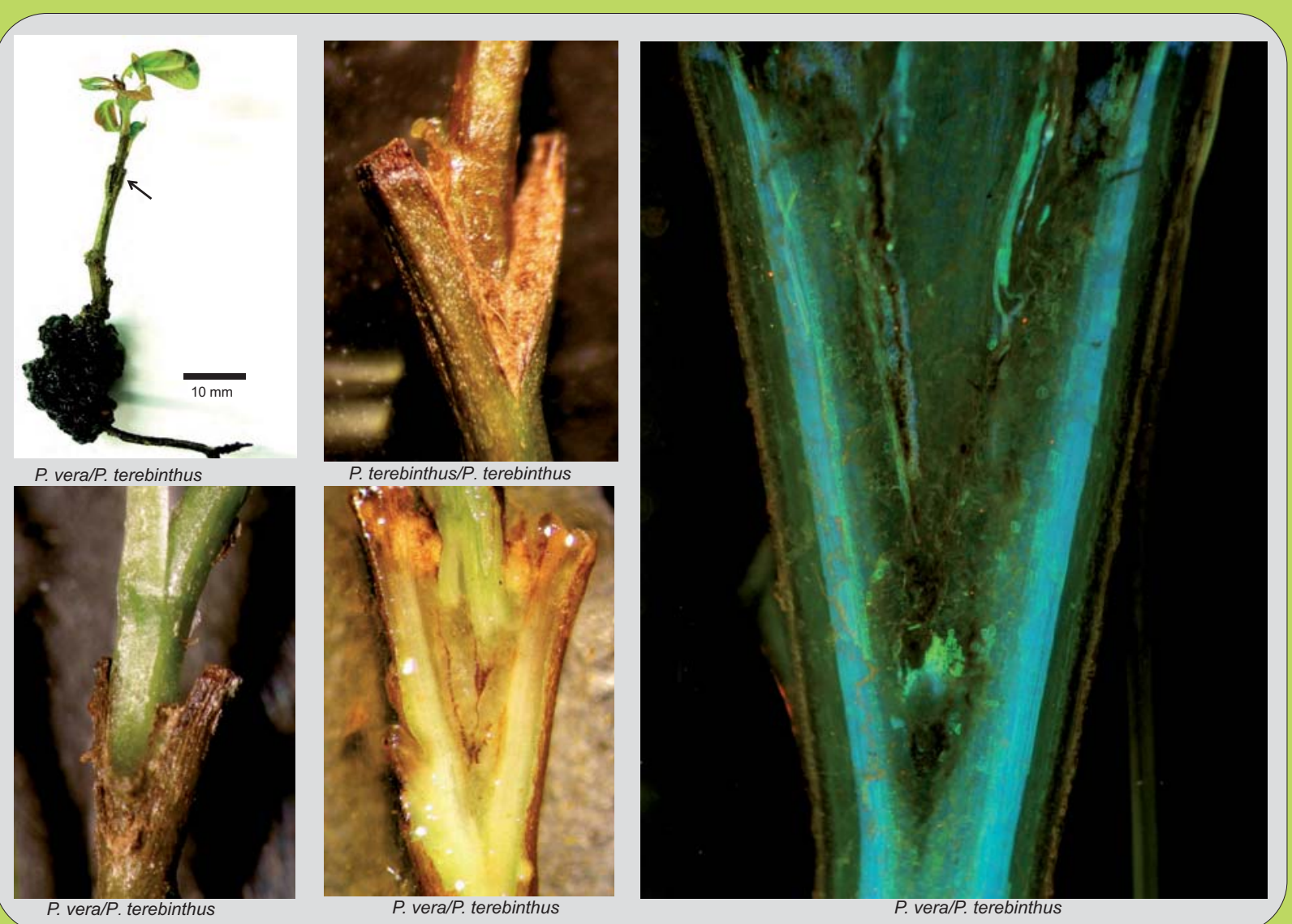

\begin{tabular}{cccccc}
\hline & $\mathrm{n}$ & Cell Proliferation & Cell Differentiation & Partial Contact & Cell Necrosis \\
\hline P. vera/P.terebinthus & 31 & $90 \%$ & $67 \%$ & $80 \%$ & $100 \%$ \\
P.terebinthus/P.terebinthus & 5 & $100 \%$ & $100 \%$ & $80 \%$ & $60 \%$ \\
\hline
\end{tabular}

This work was partially supported by the INIA-FEDER projects RTA2010-00053-C03-02 and 03 and by the Grupo de Excelencia A-43 (Gobierno de Aragón). Authors thank Carlos Benavides and Maria Reche their valuable help. 